\title{
AUDIT COMMITTEE ATTRIBUTES AND AUDIT QUALITY: A BENCHMARK ANALYSIS
}

\section{Osariemen ASIRIUWA ${ }^{1}$, Edosa Joshua ARONMWAN ${ }^{2}$ Uwalomwa UWUIGBE $^{3}$, Olubukola Ranti UWUIGBE ${ }^{4}$}

\author{
1, 3, ${ }^{4}$ Department of Accounting Covenant University, Ota-Ogun State, Nigeria \\ ${ }^{2}$ Department of Accounting Faculty of Management Sciences, University of Benin \\ E-mails: ${ }^{1}$ osariemen.asiriuwa@covenantuniversity.edu.ng; ${ }^{2}$ joshua.aronmwan@uniben.edu; \\ ${ }^{3}$ Uwalomwa.uwuigbe@covenantuniversity.edu.ng (corresponding author); ${ }^{4}$ bukola.uwuigbe@covenantuniversity.edu.ng
}

\author{
Received 22 November 2017; accepted 12 February 2018
}

\begin{abstract}
This study examined audit committee attributes and audit quality with emphasis on the specific requirements of the 2011 SEC code. The study applied the deductive approach via the expost facto research design and the Binary probit regression model in analyzing the various hypotheses put forward in study. Data used for the study were gathered for 150 firm-year observations from the annual reports of quoted companies on the floor of the Nigerian Stock Exchange. Findings from the study revealed that audit committee size, frequency of meetings, number of expertise and overall effectiveness all have a positive relationship with audit quality. However, only size and overall effectiveness was significant in their relationship. The study recommends that since the significant positive nature of audit committee effectiveness show that four attributes jointly account for effectiveness, firms are encouraged to establish audit committees that have all these attributes. Furthermore, the requirement of having a 6-member audit committee is sound and empirically proven to aid audit quality. Therefore, firms yet to subscribe to these should hasten up, while sanctions should be made for firms that do not.
\end{abstract}

Keywords: audit committee attributes, audit quality, audit committee effectiveness, audit committee size, frequency of meetings.

JEL Classification: M41, G21.

\section{Introduction}

Literature on audit quality is increasing as the time goes by. The reason for this may be hinged on the importance attached to it. After the initial work of DeAngelo in 1981 on auditor size and audit quality, there has been plethora of studies all seeking to add to the body of knowledge on the subject matter. One justification for the increasing studies on audit quality globally may be adduced to the "service nature" of auditing. Auditing involves the attestation of accounting information and provision of reasonable assurance to the users of accounting information by an independent party (Enofe et al. 2013b). This role is not tangible, as such, it is a service, and one of the hallmarks of good service is quality. Consequently, the issue of quality will continue to thrive as long as auditing involves service rendering. Nonetheless, it has been observed that there is no one generally accepted definition for this complex concept that has generated strands of discourse in the literature (International Auditing and Assurance Standards Board (IAASB) 2011).

DeAngelo (1981) in a bid to provide an understanding of this concept gave a widely used definition of audit quality as the combination of two probabilities. The first being that an auditor in the course of investigating will discover a material problem with a client's accounting system and he is also expected to make known or disclose such problem as an auditor. This reveals that this complex concept may be disintegrated into two simple areas: a discovering aspect 
and a reporting aspect. Once the first aspect is experienced, the second must follow for audit quality to be achieved. Chadegani (2011) noted that Palmrose's definition of audit quality has also been widely used as it relates audit quality to the level of assurance, knowing fully well that auditing as a service is meant to provide reasonable assurance. Looking at these definitions and others as provided in prior studies, this study prescribe that an important driver or criteria of audit quality is the capability of the auditor. For an auditor to discover a violation of the accounting system or a misstatement in the financial statement, he must be qualified and capable. More so, for an auditor to report on financial issues, he must also be capable (integrity and independence). Thus, an unqualified auditor or an incapable auditor cannot serve the meal of audit quality to users of accounting information. In other words, the study believes that evaluating audit quality requires an evaluation of the capability of the auditor.

The increasing arguments as it relates to audit quality have been adduced to the negative publicity that has surrounded the services provided by the auditor. Such negative publicities are seen from the experiences of corporate scandals witnessed globally. Specifically, companies and countries that have a fair share of the negative publicities associated with the level of audit (e.g. Enron, WorldCom, Dynegy, Adelphia, Tyco (United States); WorldCom, Pamalat (Italy); Carrian Group (Hong Kong); HIH Insurance, OneTel (Australia), Savannah bank, Societe General Bank, Intercontinental Bank, Oceanic Bank, Cadbury (Nigeria) (Odia and Ogiedu 2013, Uwuigbe 2011, Uwuigbe et al. 2017). In fact, Mgbame, Eragbhe, and Osazuwa (2012) reiterated that the continued discourse on audit quality is because of the global financial reporting scandals that seem to be a recurring decimal and has largely affected the perception and reception of accounting information users to the services rendered by both the accountant and the auditor. In a bid to provide an antidote to the plague of negative publicity and loss of positive perception of accountants, auditors and even the business world, corporate governance has been fingered (Uwuigbe et al. 2016a, Demaki 2011, IAASB 2011, Okolie 2014). The IAASB (2011) asserted that corporate governance, which is a contextual factor, is one of the three (3) important group-factor that affect audit quality. Others are the input group (e.g. auditing standard) and the output group (e.g audit report). Okolie (2014) claimed that corporate governance is simply the manner corporations are managed and runned. If they are managed well, this will rub off on audit quality and cause an improvement. Demaki (2011) opined that this expected positive effect of corporate governance on quality that has caused the Nigerian regulatory environment to come up with different codes of corporate governance. Specifically, the 2003 Security and Exchange Commission (SEC) Code as amended by the 2011 SEC code which is presently under review. Other codes include: 2006 Central Bank of Nigeria Code of Corporate Governance for Banks; 2008 National Pension Commission (PENCOM) Code of Corporate Governance for Licensed Pension Operators; 2009 National Insurance Commission Code of Good Corporate Governance for the Insurance Industry (Okolie 2014).

Apart from the Companies and Allied Matters Act (2004 as amended) that provides for the establishment of the audit committee (one out of the numerous mechanism for corporate governance), the 2003 SEC code, and subsequent codes provides rules and standards on the establishment, composition, and operations of this committee. According to Ilaboya (2005), standards are principles of best practices. They specify benchmark requirements that should be followed. As regards the operations of audit committees in Nigeria, the various codes of governance are likened to standards that prescribe how the audit committee should be established and operated. CAMA, 1990. S. 359) (3) prescribes that all public companies must have an audit committee which is to serve as a mechanism to promote quality report and reporting. It went further to state that the committee should have an equal number of directors and representatives of shareholders subject to a ceiling of six persons. Similarly, the 2011 SEC code specifies that at least one member of this committee must be a financial literate and should be able to read and understand the annual report. Although not related to the audit committee, the same code specifies that the board of directors should meet at least every quarter to carry out its responsibilities. Consequently, if the audit committee is seen as an extension of the board, as a mechanism of corporate governance just like the board, we may argue that the same duty for meetings can be drawn from the expectations for the board of directors. In all, these requirements, principles, or rules are benchmarks prescribed by the regulatory environment to aid audit quality. However, are these prescriptions based on theoretical underpinnings, casual empirics or merely a bandwagon phenomenon that characterize most developing nations?

The resource need for a member with financial experience in the committee to aid effectiveness and the need for information symmetry as well as protection of stakeholders are supported by theories like the agency theory, stakeholder theory, and even the resource dependence theory. However, these theories do not state a benchmark. Furthermore, the theory of critical mass supports the claim that a minimum number is required to cause a chain reaction or at least, cause a positive and significant impact. Though, it doesn't state what that minimum number should be. Therefore, what informed these specific benchmarks seen in our Nigerian codes and how do they affect the ability of audit committees to effectively ensure audit quality? These may serve as justification for this study. Thus, this 
study seeks to empirically investigate the benchmarks on audit committee attributes and how they affect audit quality. The study follows a deductive approach and an expo facto research design. It focuses on just public companies listed on the Nigerian Stock Exchange as they are mandated to have audit committees. It also looks at the period subsequent to the introduction of the 2011 SEC code since is it the most recent and major code of corporate governance in operation in Nigeria. The rest of this paper is divided into sections. The next section is on the issue of audit quality or quality of audit.

\section{Audit quality or quality of audit?}

Do these two mean the same? It was observed that DeAngelo (1981) used these two words (audit quality or quality of audit) interchangeably. In some part of her stu$\mathrm{dy}$, she explains the combined probability of discovering and reporting a violation in the accounting system as audit quality and in some other part; she referred to it as quality of audit services. Was this a mistake or premeditated? She relied on the simplest form of the input, process and output theory in providing her definition. Her argument based on this assumption is that auditing service is demanded by shareholders to help address the agency conflict. Thus, as an input, the auditor brings the resources (knowledge, time, skill, competence, independence, perception and others) to carry out the process (investigate, sample, verify, discover, audit environment, and others) which then leads to an output (report, opinion). If the auditor brings the right input to the process, the right output should result and thus, audit quality/quality of audit but if not, the reverse is the case. However, Duff (2004) opined that DeAngelo's definition is partial in approach as it focuses on just the technical aspect. In other words, if an auditor is technically competent, he opined that based on the definition provided, it should be audit quality not necessarily quality of audit. Duff (2004) argument for this difference is based on what is been focused. If the focus is just the output (opinion and report), then it is an issue of audit quality but if the focus is on the process (nature of the service rendered, how it was rendered), it is an issue of quality of audit, something he also termed service quality.

Figure 1 above is a diagrammatic representation of Duff (2004) idea of quality of audit. When auditing is scrutinized under the magnifying glass of the processes involved, then the concept of quality of audit comes to bear however, when it is scrutinized under the magnifying glass of just the output (as seen in Figure 2), then the concept that is readily seen is that of audit quality.

Thus, in trying to marry these two concepts, this study opines that they are not necessarily different; rather, it is dependent on the angle from which auditing as a service is viewed. It is observed that most literature focuses on audit

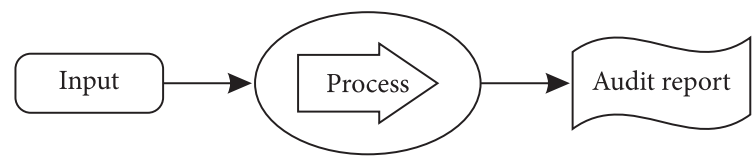

Figure 1. Quality of Audit

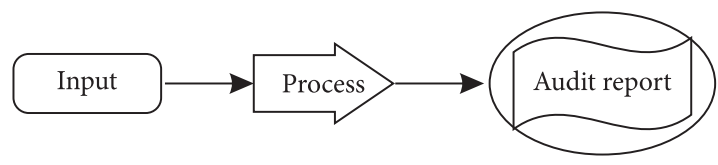

Figure 2. Audit Quality

Source: Researchers (2016)

quality rather than quality of audit. The reason is quite simple, as it is difficult to measure and quantify the process involved in auditing, and the information to do so is not readily available unlike the output, which can easily be seen. Hence, this study will basically focus on audit quality.

Furthermore, a related issue to the above is evaluating audit quality. How can audit quality be judged? Sutton and Lampe (1990) in a study involving the survey of practising auditors, evaluated audit quality with a model that captured 19 attributes of audit quality which they grouped broadly into planning, fieldwork and administrative attributes. In a similar manner, Beattie and Fearnley (1995) in their survey of attributes of auditors that account for quality audit, grouped the various attributes found into 5 groups vis audit firm integrity, audit firm reputation, professional and technical competence of audit firm, professional competence, skills and duty of care of the audit partners, and the quality of work relationship among the partners and within the firm. Duff (2004) opines that the manner the audit is carried out should be the basis for judging audit quality. Likewise, DeAngelo (1981) who already documents that the capability of an auditor to discover and also report a material problem with a client's accounting system is the basis for judging audit quality. Yuniarti (2011) suggests 7 characteristics by which audit quality can be evaluated (significance, reliability, objectivity, scope, timeliness, clarity, and efficiency). All these seem to relate more with the auditor and audit firms providing audit services. Furthermore, the Financial Reporting Council (FRC 2006) in its paper prescribe that the evaluation of audit quality be done in consideration of the culture of the audit firm, the professional skills and qualities of the employees of the audit firms (partners and other staff), the audit process just to mention a few. It is observable that premium was placed more on non-exogenous factors related to the auditor.

All these provide a platform that supports the idea that audit quality may chiefly be evaluated by considering more of the attributes and capability of the service provider. This study' evaluation of audit quality, therefore, aligns with DeAngelo (1981) and Aronmwan et al. (2013) and assert 
that audit quality can be evaluated based on the "capability" of the auditor and because this is a multifaceted concept that can be very difficult to measure; based on the product differentiation hypothesis (Simunic 1980), this attribute is captured using audit firm size (Big 4 and Non-Big 4).

\section{Measures of audit quality}

Due to the complex nature of audit quality as noted by IAASB (2011), and the difficulty in measuring actual audit quality as noted in Dang (2004); there are various measures used in prior literature to capture the concept (Chadegani 2011). These measures according to Chadegani (2011:2) include direct measures such as "financial reporting compliance with GAAP, quality control review, bankruptcy, desk review and SEC performance" and the indirect measures include "audit size, auditor tenure, industry expertise, audit fees, economic dependence, reputation and cost of capital" (Chadegani 2011: 2). Chadegani (2011) further opined that the use of direct measures is not common and it is quite challenging. The major challenge stems from the difficulty in getting data due to its private ownership hence, the popularity of the indirect measures. However, Dang (2004) in a related study argued that the measures of audit quality may not capture actual audit quality and at best, would capture perceived audit quality. The reason provided stems from DeAngelo (1981) definition of audit quality. DeAngelo (1981) in his definition describes audit quality as the "market assessed probability". This means that the assessment is based on a third party (market/public) who is not privy to actual audit process. Thus, what they assess at best is what they perceive and this perception is based on measures or proxies. Therefore, since audit quality cannot be easily observed, measures used must be a near and valid proxy to ensure reliability. Some of the most commonly used proxies include: auditor size (DeAngelo 1981, Zureigat 2011), audit fees (Aronmwan et al. 2013, Yuniarti 2011), auditor industry specialization (Abbott and Parker 2000, Jiang et al. n.d.), accruals quality (Kallapur et al. 2008, Lawrence et al. 2011). However, Chadegani (2011) and Dang (2004) opined that auditor size is the most commonly used proxy for audit quality.

\section{Concept of Audit committee}

The popularity of this concept in literature can be traced to the American Institute of Certified Public Accountants (AICPA), who in 1967 recommended the establishment of audit committee boards in order to assist with reporting process. More so, bodies such as the Tread Way Commission, Blue Ribbon committees, US Security and Exchange Commission, cannot be left out in the discourse on the development of audit committees (Blue Ribbon Committee 1999, Treadway Commission 1987).
According to Abbott, Parker and Peters (2002) and Lin, Li and Yang (2006), the recommendations of the Blue Ribbon Committee of 1999 was aimed at strengthening the effectiveness of audit committees (AC) as it relates to quality reporting and since then, studies have emerged that try to investigate the effectiveness of audit committees. Enofe, Aronmwan and Abadua (2013a) also noted that the historic development of audit committees can be seen from two broad periods: a period of obligatory establishment of audit committees (before 1978) and a period of mandatory establishment (after 1978). Audit committee can be described as a corporate governance mechanism ( $\mathrm{Li}$ et al. 2012), an arm of the board of directors (Dhaliwa et al. 2006), saddled with responsibility of ensuring quality reporting by performing oversight functions of the activities of management and external auditors (Enofe et al. 2013a) as well as help mitigate the agency problem between management and owners. Nnadi (1999) describes it as (audit committee) a company committee that should foster the independence of the external auditor. Thus, the presence of the audit committee should engender quality and independent reporting. The Sarbanes Oxley Act of 2002 defines it as a committee established by the board of directors to oversee the processes involved in accounting and auditing of company financials. According to Li et al. (2012), the audit committee can be used as an effective tool to ensure quality-reporting process. However, if this must be achieved, audit committees must possess some characteristics such as independence, frequent meetings, and financial expert as resource persons (Li et al. 2012).

\section{Audit committee size and Audit quality}

By audit committee size, in the context of this study is described as the number of persons that make up the committee. Regulatory bodies such as the Companies and Allied Matters Act (2004 as amended) and the Security and Exchange Commission code of corporate governance of 2011 have specified the number of persons that should be on the audit committee board. Specifically, the Act stipulates that audit committees must be six (6) in number and should be made up of equal numbers of directors and shareholders representatives S359 (4). For a committee to function properly, it is expected to have adequate manpower hence, the size criteria. Several studies such as (Olubukunola et al. 2016, Uwuigbe et al. 2016b, Jensen 1993, Bedard et al. 2004, Yermack 1996; etc.) have examined the relationship between the size of audit committees and audit quality. According to Jensen (1993), the audit committee monitoring oversight functions is better for companies with small-sized audit committee. The justification for this is that small boards allow for easy communication and thus, little bottlenecks in decision-making but Bedard, Chtourou and Courtea (2004) disagreed and argued that 
a large-sized audit committee would have better control and oversight function which would translate to improved audit quality as a result of having more hands to work. Lin et al. (2006) observed that a committee with at least 4 members has a significant negative relationship with earnings restatement. In the same vein, Yermack (1996) in a related study opined that a small board size vary directly with firm value. However, what number defines a small board is unknown and relative.

However, a thorough analysis from a theoretical point of view, the theory of critical mass as stated earlier supports the claim that a minimum number (persons in this case) is required to cause a chain reaction (audit quality, in this case). Thus, the theory did not provide any criteria to determine what that number is. Therefore, if regulations specify a particular number, what informed this and what will be the expected outcome? It is noted that this size criteria differs across countries. For example, while in Nigeria, a specific number (6) is expected, in the US, Lin et al. (2006) noted that the US SEC specified a minimum of 4 members while in the UK, a minimum of 3 members is specified. Thus, will the findings from these countries be different? Hence, based on the Nigerian context or environment, this study hypothesized that:

$H_{1}$ : There is a significant relationship between the size benchmark for Audit committees in Nigeria and audit quality.

\section{Audit committee meetings and Audit quality}

With respect to the recommendations of the Blue Ribbon Committee, Audit committees are expected to meet regularly in order to be effective in the discharge of its oversight functions (Abbott et al. 2002). Casual empirics suggests that a group or committee that meets regularly is expected to outperform a group or committee that does not, since it is expected to have more time to deliberate and take decisions. Bryan, Liv, and Tiras (2004) as cited in Madawaki and Amran (2013) observed that companies with audit committees that meet regularly experienced improved quality because of better transparency in reporting. They also found out that those audit committees that regularly meet are able to perform monitoring tasks more effectively than audit committees that are irregular in meeting. They recommended that such meetings should not be reactive in nature but proactive if it must be termed effective. Similarly, casual empirics suggested that committee meetings should be complementary to size criteria. That is, if audit committee size is small (in size), they would require more time to meet so as to do what probably a large sized committee would do in less time. Blue Ribbon Committee (BRC) specifically stated that audit committees should meet at least quarterly and this they argued shows the level of diligence expected from audit committees. Stewart and Munro (2007) using an experimental design, observed that respondents align to the perception that audit committee meeting; a proxy for the diligence and activity of the AC should be within 2 to 6 times in a year. Specifically, they believe that meeting just twice in a year is too infrequent to allow for effectiveness and meeting about 6 times in a year is too frequent and would be cost ineffective. Thus, they advocated for a midpoint of 4 times in a year. According to Xie, Davison and DaDalt (2003), an indirect relationship exists between the number of committee meetings and the levels of earnings management. Salawu, Okpanachi, Yahaya, and Dikki (2017) found a positive and insignificant relationship between audit committee meetings and audit quality. However, Bedard, Chtourou, and Courtteau (2004) did not find any positive association between frequency of audit committee meetings and financial reporting quality. In Nigeria, there are no regulations that are specific as to the number of meetings but this study opine that since 2011 SEC code require that the board of directors should meet at least every quarter to carry out its responsibilities. Consequently, if the audit committee is seen as an extension of the board, as a mechanism of corporate governance just like the board, we may argue that the same duty for meetings can be drawn from the expectations for the board of directors. Therefore, this study hypothesizes that:

$\mathrm{H}_{2}$ : There is a significant relationship between the meeting benchmark for Audit committees in Nigeria and audit quality.

\section{Audit committee financial expertise and Audit quality}

Unlike the size criteria that was specified by CAMA (2004), the expertise criteria was specified in Nigeria by the 2011 SEC Code, 2006 Post consolidation CBN code amongst other codes. These codes specify that at least, a member of the audit committee must possess financial management and accounting knowledge. The US SEC also has a similar condition as it expects that firms must have at least one person with financial expertise. Juhmani (2017), asserted that the availability of an accounting and financial knowledge in the audit committee would enhance its efficiency and its ability in detecting and preventing earnings management. Kibiyaa, Ahmada and Amran (2016) also buttressed in their study that the presence of a member with financial literacy or knowledgeable in accounting, finance or financial management will enhance the quality of the financial report. However, Dhaliwal et al. (2006) noted that the expertise criterion given is broad in terms of definition. They claim that persons with financial expertise can mean any of the following (1) certified public accountant, auditor, financial officers, or controllers (2) anyone that has worked in a supervisory role that involves financial statement preparation. Thus, expertise can be technical or supervisory in nature but the contention is that which of this nature of expertise is fundamental to audit quality? Is it technical/accounting or supervisory/financial management? Livingston (2003) 
provides evidence that supervisory expertise does not translate to effective understanding of accounting issues and may not ensure audit quality. This is buttressed by Dhaliwal et al. (2006) who investigated various types of expertise against audit quality and found that only accounting expertise had a significant effect on audit quality. Aronmwan et al. (2013) in their study on audit firm reputation and audit quality, controlled for audit quality using audit committee financial expertise as captured using the number of members with accounting expertise. They found an insignificant but positive relationship with audit quality. Similarly, Salawu et al. (2017) and Omoye and Aronmwan (2013) also documented an insignificant positive relationship between audit committee expertise and audit quality. In their study, expertise was captured using proportion of members with financial and accounting experience to the total board membership. Li et al. (2012) argued that audit committees having members with requisite financial expertise are in a better position to have knowledge of capital market implications of decisions and disclosures in financial statement. Such disclosures are expected to improve reporting quality and reduce information asymmetry on firm's value. Thus, based on the expectation of the codes of corporate governance in Nigeria specifying that at least one person must be able to read and interpret the financial statement, this study hypothesize that:

$\mathrm{H}_{3}$ : There is a significant relationship between the expertise benchmark for Audit committees in Nigeria and audit quality.

\section{Audit committee effectiveness and Audit quality}

Prior to the BRC recommendation, the issue on audit committee was about their effectiveness. Hence, the essence of the recommendations was to strengthen and ensure audit committee effectiveness (Lin et al. 2006). Dezoort and Salterio (2001) affirm that the construct of audit committee effectiveness is multidimensional and is affected by the various audit committee characteristics. Pucheta-Martinez and Cristina de Fuentes (2007) opined that researches on audit committee effectiveness have mostly focused on three variables viz size, nature of members and meetings of the committee. Krishnan (2005) opined that for an audit committee to be termed effective, then emphasis must be placed on its composition and diligence. In the words of Owolabi and Dada (2011), the essential attributes of an effective audit committee are seen from the extent to which its members are independent in their duties, and experienced on technical/financial matters as it may relate to reporting. Furthermore, Habbash (2010) suggest that audit committee characteristics, such as independence, expertise, and diligence are the very important factors that contribute to the effectiveness of audit committees. Based on these, it is obvious that there is no general agreement as to what attributes make up an effective audit committee but we may infer based on the BRC report and other corporate governance code that a committee that meets all the requirements as specified by the various regulation may be termed effective and therefore, ensure audit quality. Thus, effectiveness should be measured along a continuum of less effective (having just one attribute) to most effective (having all the attributes). In this regards, this study hypothesize that:

$\mathrm{H}_{4}$ : There is a significant relationship between the audit committee effectiveness and audit quality.

\section{Analytical framework and method}

This study adopts a positivism research philosophy as it seeks to make deductions and generalizations from data gathered from secondary source (annual reports of companies) and strongly believe that these data are free from human subjectivity and bias. Furthermore, this deductive study applies the expost-facto research design that observes events (activities of companies as reduced to figures) after they have occurred (reporting year). The reporting years under consideration are 2012 to 2014 and a combination of convenience and simple random sampling techniques have been utilized to arrive at a sample of 50 companies from the 194 companies listed on the Exchange as at $31^{\text {st }}$ Dec. 2014 thus, forming a 150 firm-year observation.

The analytical framework for this study is based on the agency theory, resource dependence theory and the theory of critical mass. The agency theory advocates that the separation of ownership from management results in a principal-agent crisis (Jensen and Meckling 1976). One way the crisis may occur is via information asymmetry. Therefore, to solve this, corporate governance mechanism (e.g. audit committee) should be set up to help with the quality of information been presented to the owners of business (Enofe et al. 2013a). Thus we expect that audit quality will be dependent on the presence of audit committees.

$$
\text { AQUAL }=f(A U D C O M) .
$$

According to Li et al. (2012), the audit committee can be used as an effective tool to ensure quality-reporting process.

However, if this must be achieved, audit committees must possess some characteristics. They include independence, frequent meetings, and financial expert as resource persons. Thus, in line with the resource dependence theory, if the audit committee must be effective in its duties and responsibilities, it must be well equipped in terms of resources (human, knowledge, time). Hence,

$$
\begin{gathered}
A Q U A L=f(A C S I Z E, \text { ACMT, CEXP }) ; \\
A Q U A L=f(A C E, F T) .
\end{gathered}
$$


The theory of critical mass infers that that a minimum number (e.g. persons or meetings or experts) is required to cause a chain reaction (audit quality). Furthermore, CAMA 1990 S. 359(3) prescribe that all public companies must have an audit committee having equal number of directors and representatives of shareholders subject to a ceiling of six persons. Equally, the 2011 SEC code specifies that at least one member of this committee must be a financial literate and should be able to read and understand the annual report. Therefore we expect a positive relationship between audit committee variables and audit quality.

In summary, the models to be tested in this study as expressed in econometric forms are given in equations (4) and (5) below

$$
\begin{gathered}
\operatorname{AQUAL}_{\text {it }}=\beta_{0}+\beta_{1} \operatorname{ACSIZE}_{i t}+\beta_{2} \mathrm{ACMT}_{\text {it }}+ \\
\beta_{3} \operatorname{ACEXP}_{\mathrm{it}}+\varepsilon_{\mathrm{it}} ; \\
\mathrm{AQUAL}_{\mathrm{it}}=\alpha_{0}+\alpha_{1} \mathrm{ACEFT}_{\mathrm{it}}+\mu_{\mathrm{it}},
\end{gathered}
$$

where:

$\mathrm{AQUAL}_{\text {it }}=$ Audit quality for i firm at period $\mathrm{t}$ [Captured using a dichotomous variable of one (1) if company auditor is a Big 4 and zero (0) if otherwise (Ilaboya and Ohiokha 2014)].

$\mathrm{ACSIZE}_{\text {it }}=$ Audit committee size for i firm at period $\mathrm{t}$ [captured using the specific number as required by law: one (1) if size is 6, and zero (0) if otherwise].

$\mathrm{ACMT}_{\mathrm{it}}=$ Audit committee meetings for i firm at period $\mathrm{t}$ [assigned one (1) if meetings are held at least, quarterly, and zero (0) if not (Barua et al. 2010)].

$\mathrm{ACEXP}_{\text {it }}=$ Audit committee financial expertise for $\mathrm{i}$ firm at period $t$ [captured using absolute number of audit committee members having accounting or finance experience (Emeh and Appah 2013)].

$\mathrm{ACEFT}_{\text {it }}=$ Audit committee effectiveness for i firm at period $t$ [using a similar approach in Krishnan (2005), we captured ACEFT using the 4 commonly used audit committee characteristics: independence, size, expertise, and meetings. The sum of these variables measured dichotomously signifies the level of effectiveness].

$\beta_{0}, \beta_{1}, \beta_{2}, \beta_{3}, \alpha_{0}, \alpha_{1}=$ Coefficient of variables.

Aprior expectations: $\beta_{1}>1, \beta_{2}>1, \beta_{3}>1, \alpha_{1}>1$.
Based on the nature of the dependent variable (audit quality) which is captured using a dummy of 1 and 0 , the specified model is analyzed using the binary regression technique, as the classical regression technique will not be suited for a dichotomous dependent variable. We assume that the cumulative distribution follows a standard normal distribution thus; the probit form of binary regression technique is used.

\section{Results and interpretations}

Table 1 describes the characteristics of the variables used in this study. The mean value for Audit quality (AQUAL) is 0.61 suggesting that more than half of the sampled companies employ the services of the Big 4 audit firms. Based on this, we may infer that the extent of audit quality is slightly above average for the sampled firms. The mean for Audit committee size (ACSIZE) is 0.72 indicating that $72 \%$ of firms complied with the size criteria specified by CAMA (2004 as amended) by having exactly six (6) on the audit committee board. Similarly, the 0.62 that represents the mean for Audit committee meetings (ACMT) indicates that $62 \%$ of firms have at least, 4 meetings in a year. On the average, (ACEXP) having a mean of 1.28 implies that the number of financial experts present on audit committee boards is majorly 1 out of the 6-member board. Similarly, the mean for Audit committee effectiveness (ACEFT) stood at 2.49, signaling that the summary score for effectiveness of audit committee lies between 2 and 3. This shows that audit committee boards are averagely effective.

As regards the dispersion and normality of the individual variables, the small standard deviations suggest that actual values of individual firms are minimally dispersed from the mean, while the significance of the p-values of the Jarque-Bera statistics infer normality except for ACEFT that is not normally distributed. When compared against figure 3 (histogram), the p-value of the JB statistics shows that the series taken jointly is normally distributed. The skewness of -0.44 indicates that the series is skewed towards the left. The kurtosis of 1.50 signals a distribution that is flat and not peaked. In summary, the normality test has been passed by the distribution and it is safe to assume that the distribution follows a normal curve.

Table 1. Descriptive statistics

\begin{tabular}{|l|c|c|c|c|c|}
\hline & AQUAL & ACSIZE & ACMT & ACEXP & ACEFT \\
\hline Mean & 0.613333 & 0.720000 & 0.626667 & 1.280000 & 2.493333 \\
\hline Std. Dev. & 0.488618 & 0.450503 & 0.485310 & 0.450503 & 0.817154 \\
\hline Jarque-Bera & 25.29334 & 30.76381 & 25.47031 & 30.76381 & 4.118265 \\
\hline Probability & 0.000003 & 0.000000 & 0.000003 & 0.000000 & 0.127565 \\
\hline
\end{tabular}

Source: Researchers compilation (2016) 

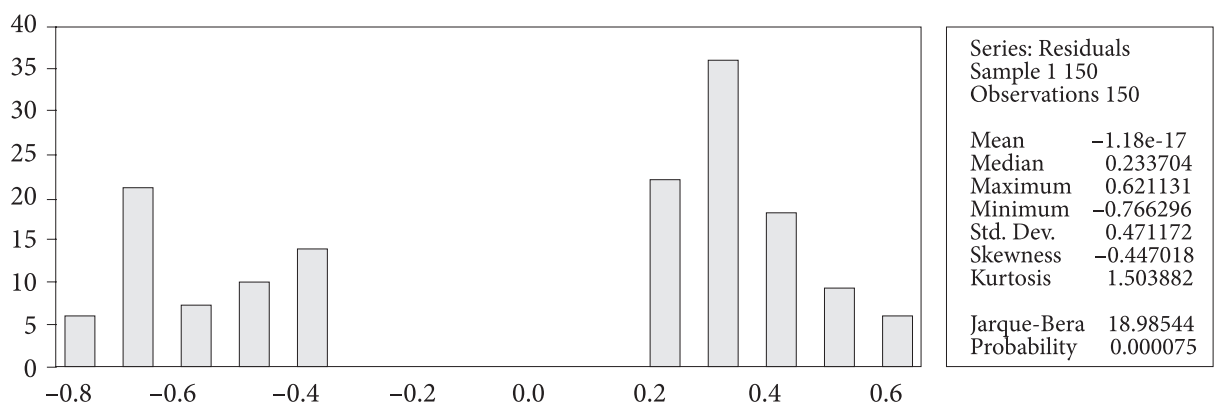

Figure 3. Distribution Histogram. Source: Researchers compilation 2016

Table 2. Correlation Matrix

Covariance Analysis: Ordinary

\begin{tabular}{|c|c|c|c|c|c|}
\hline Correlation Probability & AQUAL & ACSIZE & ACMT & ACEXP & ACEFT \\
\hline AQUAL & 1.000000 & & & & \\
\hline ACSIZE & $\begin{array}{c}0.236597 \\
(0.0036)\end{array}$ & 1.000000 & & & \\
\hline ACMT & $\begin{array}{c}0.151324 \\
(0.0645)\end{array}$ & $\begin{array}{c}0.255400 \\
(0.0016)\end{array}$ & 1.000000 & & \\
& 0.129274 & 0.223545 & 0.112965 & 1.000000 & $(0.1687)$ \\
\hline ACEXP & $(0.1149)$ & $(0.0060)$ & 0.223878 & $(0.0059)$ & 1.000000 \\
\hline
\end{tabular}

Source: Researchers compilation (2016)

Table 3. Model 1

Dependent Variable: AQUAL

\begin{tabular}{|c|c|c|c|c|}
\hline \multicolumn{5}{|c|}{ Method: ML - Binary Probit (Quadratic hill climbing) } \\
\hline Variable & Coefficient & Std. Error & z-Statistic & Prob. \\
\hline $\mathrm{C}$ & -0.555090 & 0.350526 & -1.583589 & 0.1133 \\
\hline ACSIZE & 0.548264 & 0.244573 & 2.241713 & 0.0250 \\
\hline ACMT & 0.250586 & 0.224824 & 1.114590 & 0.2650 \\
\hline ACEXP & 0.237241 & 0.248177 & 0.955937 & 0.3391 \\
\hline McFadden R-squared & 0.052561 & \multicolumn{2}{|c|}{ Mean dependent var } & 0.613333 \\
\hline S.D. dependent var & 0.488618 & \multicolumn{2}{|l|}{ S.E. of regression } & 0.475937 \\
\hline Akaike info criterion & 1.317660 & \multicolumn{2}{|c|}{ Sum squared resid } & 33.07133 \\
\hline Schwarz criterion & 1.397944 & \multicolumn{2}{|l|}{ Log likelihood } & -94.82453 \\
\hline Hannan-Quinn criter. & 1.350277 & \multicolumn{2}{|l|}{ Deviance } & 189.6491 \\
\hline Restr. Deviance & 200.1701 & \multicolumn{2}{|c|}{ Restr. log likelihood } & -100.0851 \\
\hline LR statistic & 10.52105 & \multicolumn{2}{|c|}{ Avg. log likelihood } & -0.632164 \\
\hline Prob(LR statistic) & 0.014619 & & & \\
\hline Obs with Dep $=0$ & 58 & \multicolumn{2}{|l|}{ Total obs } & 150 \\
\hline Obs with Dep $=1$ & 92 & & & \\
\hline
\end{tabular}

Source: Researchers compilation (2016) 
The correlation matrix as seen in Table 2 is used to show the strength of the relationship between the variables. The strength of the relationship between AQUAL and ACSIZE is weak $(0.23, \mathrm{p}<0.05)$, between AQUAL and ACMT is weak $(0.15, \mathrm{p}<0.05)$, between AQUAL and ACEXP is poor ( 0.15 , $\mathrm{p}>0.05)$ and between AQUAL and ACEFT is also weak $(0.24, \mathrm{p}<0.05)$. Looking at the interrelationship between the independent variables, all the variables are strongly related to ACEFT. This is expected since Audit committee effectiveness (ACEFT) is a summary score of the individual variables. Therefore, to avoid bias and multicollinearity issues in the result, (ACEFT) will be regressed alone against Audit quality (AQUAL) for testing the last hypothesis.

Table (3) is the estimation of model 1. Looking at the individual statistics of the variables, the $\mathrm{Z}$ statistics and associated p-values explain the significance or otherwise the association between the dependent and the independent variables. ACSIZE has a statistics of $(2.24, \mathrm{p}=0.02)$. This outcome indicates that Audit committee size (ACSIZE) is significantly associated with Audit quality (AQUAL). The coefficient of 0.54 implies that the association is positive. Also, findings as depicted in Table (3) shows that audit committee meetings (ACMT) has a statistics value of (1.11, $\mathrm{p}=0.26)$. This result implies that the positive association between ACMT and AQUAL is not significant. Similarly, result on the association between audit committee financial expertise (ACEXP) and Audit quality (AQUAL) as depicted in table (3), presents a statistics value of $(0.95, \mathrm{p}=0.33)$. This outcome invariably implies that the positive association between ACEXP and AQUAL is also not significant. In summary, at $5 \%$ significance level, audit committee size (ACSIZE has a significant positive relationship with
Table 4. Goodness of Fit (model 1)

Goodness-of-Fit Evaluation for Binary Specification

\begin{tabular}{|l|l|l|l|}
\hline \multicolumn{4}{|l|}{ Andrews and Hosmer-Lemeshow Tests } \\
\hline Equation: UNTITLED \\
\hline H-L Statistic & 12.8923 & Prob. Chi-Sq(8) & 0.1156 \\
\hline Andrews Statistic & 22.2599 & Prob. Chi-Sq(10) & 0.0138 \\
\hline
\end{tabular}

Source: Researchers compilation (2016)

AQUAL while ACMT and ACEXP have insignificant positive relationships with AQUAL. The McFadden R-squared shows that ACSIZE, ACMT, and ACEXP jointly explain about $5 \%$ of the systematic variation in AQUAL. The LR statistics of 10.52 and the associated $p$-value of 0.01 provide evidence that the model is statistically significant and sound in explaining the relationship between the dependent and independent variables.

Table 4 provides evidence of the goodness of fit of model 1 and therefore, serves as backing for the reliance of the statistics of the model. When the p-values are less than 0.05 , it suggest that the model provides a line that is sufficiently fitted. Looking at table 4 , the HL statistics has a p-value that is greater than 0.05 while the Andrews statistics has a p-value that is less than 0.05 . This mix finding suggests that caution be made in interpreting the result of the model estimation.

Table (5) is the estimation of model 2. ACEFT has a statistics of $(2.96, \mathrm{p}=0.003)$. These show that it is significantly associated with AQUAL. The coefficient of 0.39 also shows that this association is positive. Therefore, at $5 \%$ significance level, ACEFT has a significant positive relationship with AQUAL. The McFadden R-squared shows that ACEFT

Table 5. Model 2

Dependent Variable: AQUAL

\begin{tabular}{|l|c|c|c|c|}
\hline \multicolumn{5}{|c|}{ Method: ML - Binary Probit (Quadratic hill climbing) } \\
\hline Variable & Coefficient & \multicolumn{1}{c|}{ Std. Error } & z-Statistic & Prob. \\
\hline C & -0.675449 & 0.340666 & -1.982730 & 0.0474 \\
\hline ACEFT & 0.390803 & 0.131744 & 2.966385 & 0.0030 \\
\hline McFadden R-squared & 0.045402 & Mean dependent var & 0.613333 \\
\hline S.D. dependent var & 0.488618 & S.E. of regression & 0.474692 \\
\hline Akaike info criterion & 1.300547 & Sum squared resid & 33.34926 \\
\hline Schwarz criterion & 1.340689 & Log likelihood & -95.54101 \\
\hline Hannan-Quinn criter. & 1.316855 & Deviance & 191.0820 \\
\hline Restr. Deviance & 200.1701 & Restr. log likelihood & -100.0851 \\
\hline LR statistic & 9.088085 & Avg. log likelihood & -0.636940 \\
\hline Prob(LR statistic) & 0.002573 & & & \\
\hline Obs with Dep=0 & 58 & Total obs & & 150 \\
\hline Obs with Dep=1 & 92 & & & \\
\hline
\end{tabular}

Source: Researchers compilation (2016) 
Table 6. Goodness of Fit (model 2)

Goodness-of-Fit Evaluation for Binary Specification

\begin{tabular}{|l|c|l|l|}
\hline \multicolumn{4}{|l|}{ Andrews and Hosmer-Lemeshow Tests } \\
\hline \multicolumn{4}{|l|}{ Equation: UNTITLED } \\
\hline H-L Statistic & 13.8787 & Prob. Chi-Sq(8) & 0.0850 \\
\hline Andrews Statistic & 16.0734 & Prob. Chi-Sq(10) & 0.0976 \\
\hline
\end{tabular}

Source: Researchers compilation (2016)

explain about $4 \%$ of the systematic variation in AQUAL. The LR statistics of 9.08 and associated p-value of 0.002 provide evidence that the model is statistically significant and sound in explaining the relationship between ACEFT and AQUAL.

Table 6 provides evidence of the goodness of fit of model 2. The HL statistics and Andrews statistics have p-values that are greater than 0.05 but less than 0.10 . Thus, at $10 \%$ significance, the fitness of the model shows that reliance can be placed on the result.

\section{Hypotheses and discussions}

The decision rule to test the hypotheses is that at $5 \%$ significance level, we fail to accept the null hypothesis and accept the alternate, if the probability value of the $\mathrm{z}$-statistics is less than 0.05 or vice versa. Based on the result as presented in Table 3, ACSIZE has a p-value that is less than 0.05 consequently, the study accept the alternate hypothesis that ACSIZE has a significant positive relationship with AQUAL. This finding shows that an audit committee with a size of 6 as specified by the law helps to improve audit quality. Thus, the recommendation by CAMA (2004 as amended) has been validated empirically to be reliable. This finding further confirms the critical mass theory and proves that a committee size of 6 is enough to cause a positive impact on audit quality. This finding also supports the earlier findings of Lin et al. (2006) but negates the findings of Bedard et al. (2004). Also, findings as indicted in Table 3 , indicates that ACMT has an insignificant relationship with AQUAL although the relationship is positive. This shows that a committee that meets at least 4 times in a year can aid audit quality, but the extent of its impact may not be significant or consequential. The insignificant nature of this finding may be hinged on the qualification of members who attend. If committee members meet regularly but lack requisite skills or qualifications, such meetings may prove useless and thus inconsequential. This may account for the insignificant finding when compared with the insignificant finding of audit committee expertise. This finding contradicts the finding of Bedard et al. (2004) but supports the finding of Xie et al. (2003).

The result from Table 3 also shows that ACEXP has an insignificant relationship with AQUAL though the relationship is positive. What this implies is that as the quality of expertise of audit committee members increase, so does the quality of audit. The implication of this finding on the requirement of the $2011 \mathrm{SEC}$ code is that having at least one member of the audit committee as a financial expert will aid audit quality but the impact of this is not significant. Thus, experts on audit committee boards may or may not cause quality audit. This outcome may be due to the work nature of audit committee members. It is possible that even with the requirement of having at least one expert in accounting and finance as an audit committee member, such member may be belabored with so much responsibilities that rob such member of efficiency. Furthermore, the insignificant nature of this finding may be due to the lack of clarity on the definition of an expert. According to Dhaliwal et al. (2006), a financial expert may be an expert in accounting or finance or general business. The impact of these types of experts will ordinarily be different. Thus, the insignificant nature of this finding may be due to the quality of experts as this was captured using the definition specified by 2011 SEC code. This finding also supports the earlier findings of Aronmwan et al. (2013), Omoye and Aronmwan (2013) but negates the findings of Madawaki and Amran (2013).

Lastly, Table 5 shows that audit committee effectiveness has a significant and positive relationship with audit quality. The Blue Ribbon committee advocated that effectiveness of audit committee is key in improving audit quality. This finding provides empirical evidence to support the committee's recommendation. Audit effectiveness was measured as a summary score of having an audit committee of 6 that meets at least 4 times in a year, having at least an accounting or finance expert and is equally independent. Based on this measure, findings from this study shows that such committee would aid audit quality more than a committee that lacks any of the requirements. This finding aligns with general findings in this area. It specifically aligns with the findings of Zaman, Hudaib and Haniffa (2011), Bedard et al., (2004) and Xie et al. (2003).

Based on the findings, this study therefore recommends that: The requirement of having a 6-member audit committee is sound and empirically proven to aid audit quality. Therefore, firms yet to subscribe to these should hasten up and sanctions be made for firms that do not. The insignificant finding on the number of meetings shows that it is not a major requirement for effectiveness of the audit committee. Thus, there is no need to make a strict requirement in this regards as it was done for the board of directors and audit committees should freely meet based on the circumstances faced by individual firms. The significant positive nature of audit committee effectiveness show that four attributes jointly account for effectiveness vis independence, size (6), meetings (at least quarterly) and expertise (at least 1). Therefore, firms are encouraged to establish audit committees that have all these attributes if audit quality must be encouraged. 


\section{Conclusion}

Having examined audit committees in Nigeria and benchmarked their attributes to the requirements of the 2011 SEC code, we conclude based on the positive relationship of all the variables examined that the requirements as specified in the code indeed adds to audit quality. More importantly, based on the significance of audit committee effectiveness which is dependent on the presence of other audit committee attributes, we conclude that regulatory bodies such as Security and Exchange Commission, Nigerian Stock Exchange and others should make it mandatory for companies to meet these minimum audit committee attribute requirements if audit quality must be at a high standard.

\section{Limitations/Future research}

The insight provided by this study notwithstanding, this research has limitations which would motivate further research. Future research could investigate other audit committee attributes such as gender or even the specific nature of expertise (accounting or finance or business).

\section{References}

Abbott LJ, Parker S (2000). Auditor selection and audit committee characteristics. Auditing: Journal of Practice and Theory 19 (2): 47-66. https://doi.org/10.2308/aud.2000.19.2.47

Abbott LJ, Parker S, Peters, GF (2002). Audit committee characteristics and financial misstatement: a study of the efficacy of certain Blue ribbon committee recommendations www. researchgate.net

Aronmwan EJ, Ashafoke TO, Mgbame CO (2013) Audit firm reputation and audit quality. European Journal of Business and Management 5 (7): 66-75.

Barua A, Rama DV, Sharm V (2010) Audit committee characteristics and investment in internal auditing. Journal of Accounting and Public Policy 29 (2010): 503-513. https:// doi.org/10.1016/j.jaccpubpol.2010.09.001

Beattie V, Fearnley S (1995) The importance of audit firm characteristics and the drivers of auditor change in UK listed companies. Accounting and Business Research 25 (2): 227 239. https://doi.org/10.1080/00014788.1995.9729912

Bedard J, Chtourou SM, Courteau L (2004) The effect of audit committee expertise, independence, and activity on aggressive earnings management. Auditing: A Journal of Practice \& Theory 23 (2): 13-35. https://doi.org/10.2308/aud.2004.23.2.13

Blue Ribbon Committee (BRC) (1999) Report and Recommendation of the Blue Ribbon Committee on Improving effectiveness of Corporate Audit Committees. USA: NY, New York Stock Exchange and National Association of Securities Dealers.

Bryan, D. M., Liv, C., Tiras, S. L. (2004). The influence of independent and effective audit committees on earnings quality SSRN.com/abstract $=488082$

Chadegani AA (2011) Review of studies on audit quality. International Conference on Humanities, Society and Culture 20 (2011): 312-315.
Companies and Allied Matters Act (CAMA) (2004) Lagos: Federal Government printer.

Dang L (2004) Assessing actual audit quality. Doctoral Thesis from Drexel University, Philadelphia, USA.

DeAngelo LE (1981) Auditor size and audit quality. Journal of Accounting and Economics 3 (3): 183-199. https://doi. org/10.1016/0165-4101(81)90002-1

Demaki GO (2011) Proliferation of codes of corporate governance in Nigeria and economic development. Business and Management Review 1 (6): 1-7.

Dezoort FT, Salterio SE (2001) The effects of corporate governance experience and financial reporting and audit knowledge on audit committee members' judgments. Auditing: A Journal of Practice \& Theory 20 (2): 31-47. https://doi.org/10.2308/ aud.2001.20.2.31

Dhaliwal D, Naiker V, Navissi F (2006) Audit committee financial expertise, corporate governance and accruals quality: an empirical analysis www.researchgate.net

Duff A (2004) Audit quality: dimensions of audit quality. Edinburgh, The institute of Chartered Accountants of Scotland.

Emeh Y, Appah E (2013) Audit committee and timeliness of financial reports: Empirical evidence from Nigeria. Journal of Economic and Sustainable Development 4 (20): 14-25.

Enofe AO, Aronmwan EJ, Abadua HS (2013a) Audit committee report in corporate financial statements: Users' perception in Nigeria. European Journal of Accounting Auditing and Finance Research 1 (1): 16-28.

Enofe AO, Mgbame C, Aderin A, Ehi-Oshio OU (2013b) Determinants of audit quality in the Nigerian business environment. Research Journal of Finance and Accounting 4 (4): 36-43.

FRC (2006) Promoting audit quality: Discussion Paper. London: Financial Reporting Council.

Habbash M (2010) The effectiveness of corporate governance and external audit on constraining earnings management practices in UK: Doctoral thesis. Durham University http:// etheses.dur.ac.UK/448/.

IAASB (2011) Audit quality: An IAASB perspective. USA: NY, International Auditing and Assurance Standards, Board.

Ilaboya OJ (2005) Advanced Financial Accounting. Benin City, Mindex Publishers.

Ilaboya OJ, Ohiokha FI (2014) Audit firm characteristics and audit quality in Nigeria. International Journal of Business and Economics Research 3 (5): 187-195. https://doi.org/10.11648/j. ijber.20140305.14

Jensen M (1993) Modern industrial revolution, exit and failure of internal control system. Journal of finance 48(3): 831-880. https://doi.org/10.1111/j.1540-6261.1993.tb04022.x

Jensen, M. C., Meckling, W. H. (1976). Theory of the firm: Managerial behavior, agency costs and ownership structure. Journal of Financial Economics, 3(4): 305-360.

Jiang L, Jeny-Cazavan A., Audousset-Coulier S (n.d.). Who are industry specialist? 1-32.

Juhmani OI (2017) The impact of audit committee characteristics on earnings management in the pre- and post- Bahraini corporate governance code 2011. Asian Journal of Economics, Business and Accounting 4 (3): 1-12. https://doi.org/10.9734/ AJEBA/2017/36234 
Kallapur S, Sankaraguruswamy S, Zang Y (2008) Audit market competition and audit quality, 1-30.

Kibiyaa MU, Ahmada AC, Amran NA (2016) Audit committee characteristics and financial reporting quality: Nigerian nonfinancial listed firms. The European Proceeding of Social \& Behavioural Sciences, 753-760. https://doi.org/10.15405/ epsbs.2016.08.106

Krishnan J (2005) Audit committee quality and internal control: an empirical analysis. The Accounting Review 80 (2): 649-675. https://doi.org/10.2308/accr.2005.80.2.649

Lawrence A, Minutti-Meza M, Zhang P (2011) Can big 4 versus non-big 4 differences in audit-quality proxies be attributed to client characteristics? The Accounting Review 86 (1): 259-286. https://doi.org/10.2308/accr.00000009

Li J, Mangena M, Pike R (2012) The effect of audit committee characteristics on intellectual capital disclosure. The British Accounting Review 44 (2012): 98-110. https://doi. org/10.1016/j.bar.2012.03.003

Lin JW, Li JF, Yang SY (2006) The effect of audit committee performance on earnings quality. Managerial Auditing Journal 21 (9): 921-933. https://doi.org/10.1108/02686900610705019

Livingston, P. (2003). Financial experts on audit committees. Financial Executive 19: 6-7.

Madawaki A, Amran NA (2013) Audit committees: how they affect financial reporting in Nigerian Companies. Journal of Modern Accounting and Auditing 9 (8): 1070-1080.

Mgbame CO, Eragbhe E, Osazuwa NP (2012) Audit partner tenure and audit quality: an empirical analysis. European Journal of Business and Management 4 (7): 154-162.

Nnadi GA (1999) Making audit committees effective. ICAN News, October/November, 6-9.

Odia JO, Ogiedu KO (2013) Corporate governance and earnings management in the Nigerian banking industry. ESUT Journal of Accountancy 4 (1): 238-243.

Okolie JU (2014) Corporate governance and audit committee in Nigeria. Journal of Policy and Development Studies 9 (1): 226-233. https://doi.org/10.12816/0011193

Omoye AS, Aronmwan EJ (2013) Audit firm rotation and audit quality in the Nigerian banking sector. Benin Journal of Social Sciences 21 (2): 34-43.

Owolabi SA, Dada SO (2011) Audit committee: an instrument of effective corporate governance. European Journal of Economics Finance and Administrative sciences 35: 173-184.

Pucheta-Martinez MC, Cristina de Fuentes (2007) The impact of audit committee characteristics on the enhancement of the quality of financial reporting: an empirical study in the Spanish context. Journal Compilation 15 (6): 1394-1412. https://doi.org/10.1111/j.1467-8683.2007.00653.x

Salawu OM, Okpanachi JO, Yahaya OA, Dikki CA (2017) Effects of audit committee expertise and meeting on audit quality of listed consumer-goods companies in Nigeria. European Journal of Accounting, Auditing and Finance Research 5 (10): 61-79.
SEC (2011) Code of Corporate Governance for Public Companies in Nigeria. Abuja. SEC.

Simunic D (1980) The pricing of audit services: theory and evidence. Journal of Accounting Research (Spring), 161-190. https://doi.org/10.2307/2490397

Stewart J, Munro L (2007) The impact of audit committee existence and audit committee meeting frequency on the external audit: perceptions of Australian auditors. International Journal of Auditing 11: 51-69. https://doi.org/10.1111/j.10991123.2007.00356.x

Sutton S, Lampe J (1990) Formulating a process measurement system for audit quality. Proceedings of University of Southern California Audit Judgment Symposium.

Treadway Commission (1987) The report of the national commission on fraudulent financial reporting, National Commission on Fraudulent Financial Reporting, Washington D.C.

Uwuigbe OR (2011) Corporate governance and financial performance of banks in Nigeria: Master's thesis. Covenant university, Ota, Nigeria.

Olubukunola RU, Uwuigbe U, Iyoha F, Omankhanlen AE (2016) Globalizing the Board and Financial Performance: evidence from Nigerian Banks. Indian Journal of Finance 10 (9): 66-79. https://doi.org/10.17010/ijf/2016/v10i9/101481

Uwuigbe U, Agba LU, Jimoh J, Olubukunola RU, Rehimetu J (2017) IFRS adoption and earnings predictability: evidence from listed banks in Nigeria. Banks and Bank Systems 12 (1): 166-174. https://doi.org/10.21511/bbs.12(1-1).2017.10

Uwuigbe U, Francis KE, Uwuigbe OR, Ataiwrehe CM (2016a) International financial reporting standards adoption and accounting quality: evidence from the Nigerian banking sector. Corporate Ownership \& Control 14 (1): 287-294. https://doi.org/10.22495/cocv14i1c1p12

Uwuigbe U, Uwuigbe OR, Ebeguki EI, Jinadu O, Otekunrin A (2016b) The effect of financial performance and board size on corporate executive compensation: a study of selected listed banks in Nigeria. Journal of Internet Banking and Commerce 21 (3).

Xie B, Davidson WN, DaDalt PJ (2003) Earnings management and corporate governance: the role of the board and the audit committee. Journal of Corporate Finance 9 (3): 295-316. https://doi.org/10.1016/S0929-1199(02)00006-8

Yermack D (1996) Higher market valuation of companies with small board of directors. Journal of Financial Economics 40 (2): 185-211. https://doi.org/10.1016/0304-405X(95)00844-5

Yuniarti R (2011) Audit firm size, audit fee and audit quality. Journal of Global Management 2 (1): 84-97.

Zaman M, Hudaib M, Haniffa R (2011) Corporate governance quality, audit fees and non-audit services fees. Journal of Business Finance and Accounting 38 (1/2): 165-197. https:// doi.org/10.1111/j.1468-5957.2010.02224.x

Zureigat QM (2011) The effect of ownership structure on audit quality: evidence from Jordan. International Journal of Business and Social Science 2 (10): 38-46. 